\title{
【特集II】〈第25回日本外科系連合学会学術集会ビデオシンボジウム2〉 甲状腺・乳腺・副督の内視鏡下手術
}

\section{6. 乳癌に対する内視鏡下乳房温存手術}

\author{
日本大学第 3 外科 \\ 山形 基夫 三上 元 長谷川哲夫 \\ 笠倉雄一岩井重富高山忠利
}

\section{Endoscopic Breast Conseving Surgery}

Motoo YAMAGATA, Gen MIKAMI, Tetsuo HASEGAWA, Yuichi KASAKURA, Shigetomi IWAI and Tadatoshi TAKAYAMA

3rd Department of Surgery, Nihon University

現在本邦で施行されている内視鏡下乳房温存手術は良性腫瘍に対する外側アプローチ法乳輪下アプローチ法, 覀性腫瘍に对して腋窝アプローチ法, 乳輪下アプローチ法が施行されている。乳腺に对する内視鏡下手術は乳癌 という疾患の特性上良い適応であり，手術創の縮小化と位置の移動により手術効果を損なうことなく高い整容性 が期待できる。われわれの術式は乳輪下アプローチ法による内視鏡補助下乳腺切除術および剝離バルーンを用い た気襄下腋窩リンパ節郭清術より構成されている本法は短期的には通常術式と比較して手術効果に差がなく術 者の習熟度を補う有用な手段であり，今後ますます発展する術式であると考之られる。

索引用語：内視鏡下乳房手術 (endoscopic breast surgery), 乳房温存手術 (breast conserving surgery)

\section{はじめに}

体表特に露出部およびその近傍の疾患に対する 外科手術では従来より手術創を目立たなくするた め様々な努力がなされてきたがその技術は熟練を 要するものであった。一方体表の疾患に対する内 視鏡下術手術は本法の特徴である遠隔操作を応用 することで手術創を縮小化するだけでなく，手術 創そのものを目立たない部位へ移動させることが 可能で露出部に手術㓔痕を残すことなく手術がで き, 高い整容性が期待できる。現在, 本邦で施行さ れている内視鏡下乳房温存術式は腋窩アプローチ を用いた吊り上げ法, 気囊下乳腺全摘術および乳 輪下アプローチ法などがあり,施設によって種々の 工夫がなされている。本稿では腋窩アプローチ法に ついて実際の術式とその手術成績について述べる。

\section{$\mathrm{A}$ ，手術の実際}

われわれの術式は乳輪下アプローチ法による内 視鏡補助下乳腺切除術および気囊下腋窩リンパ節 郭清術より構成されている。

1 , 麻酔; 麻酔は調整呼吸による全身麻酔で気囊 下腋窩リンパ節郭清術施行時には炭酸ガス貯留防 止のため換気回数をやや多めに設定する。

2 , 手術器具; 本術式に使用する器具は直視鏡, 斜視鏡 (30度), 胸腔鏡下手術様鉗子および剪刀, 剝離用バルーン (PDB, Tyco社製), Blunt port

(Tyco社製)，VISIPORT(Tyco社製)，10mmお よび $5 \mathrm{~mm}$ トロカール (できれば短いもの), 超音 波凝固装置 (Coagulating shiears以下CS, ハーモ ニックスカルペル，エチコン社製を使用)，筋鉤， 色素等が必要で乳腺部分切除では創縁鉗子, 止血 鉗子など通常の手術器械も必要である。 


\section{6. 乳癌に対する内視鏡下乳房温存手術}

\section{3，体位}

体位は上肢を屈曲させると腋窩りンパ節郭清時 の手術操作の妨げとなるため前腕を伸展させ，頭 側に挙上した体位での固定が望ましい（図 1 )。

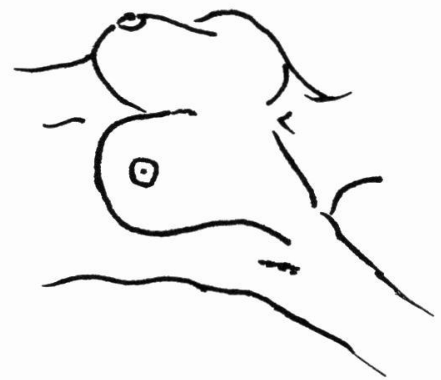

図 1 患者体位

\section{4 , 乳腺部分切除術}

本術式は通常の術式で困難な小切開創から，皮 弁形成, 筋膜剥離等乳腺の広範用な剥離操作を内 視鏡を用いて行い, その後の乳腺切除は通常の方 法と同様に直視下に行う方法である。可視卜ロカ 一ルによる皮弁作製操作の原理は血管を含む皮下 組織を圧排かつ伸展させることでこれらの組織を トンネル間の中隔に集めることを目的とした操作 であり，皮下組織をトロカールによって切離する 操作ではない。したがって本法は腫瘍直上の皮下 組織についても十分なマージンを確保でき，皮膚 腫瘍間距離がトロカールの直径より小さい場合を 除き，鋭的に作製した皮弁と比較して皮弁下残存 組織の状態など手術効果には差がないものと考え
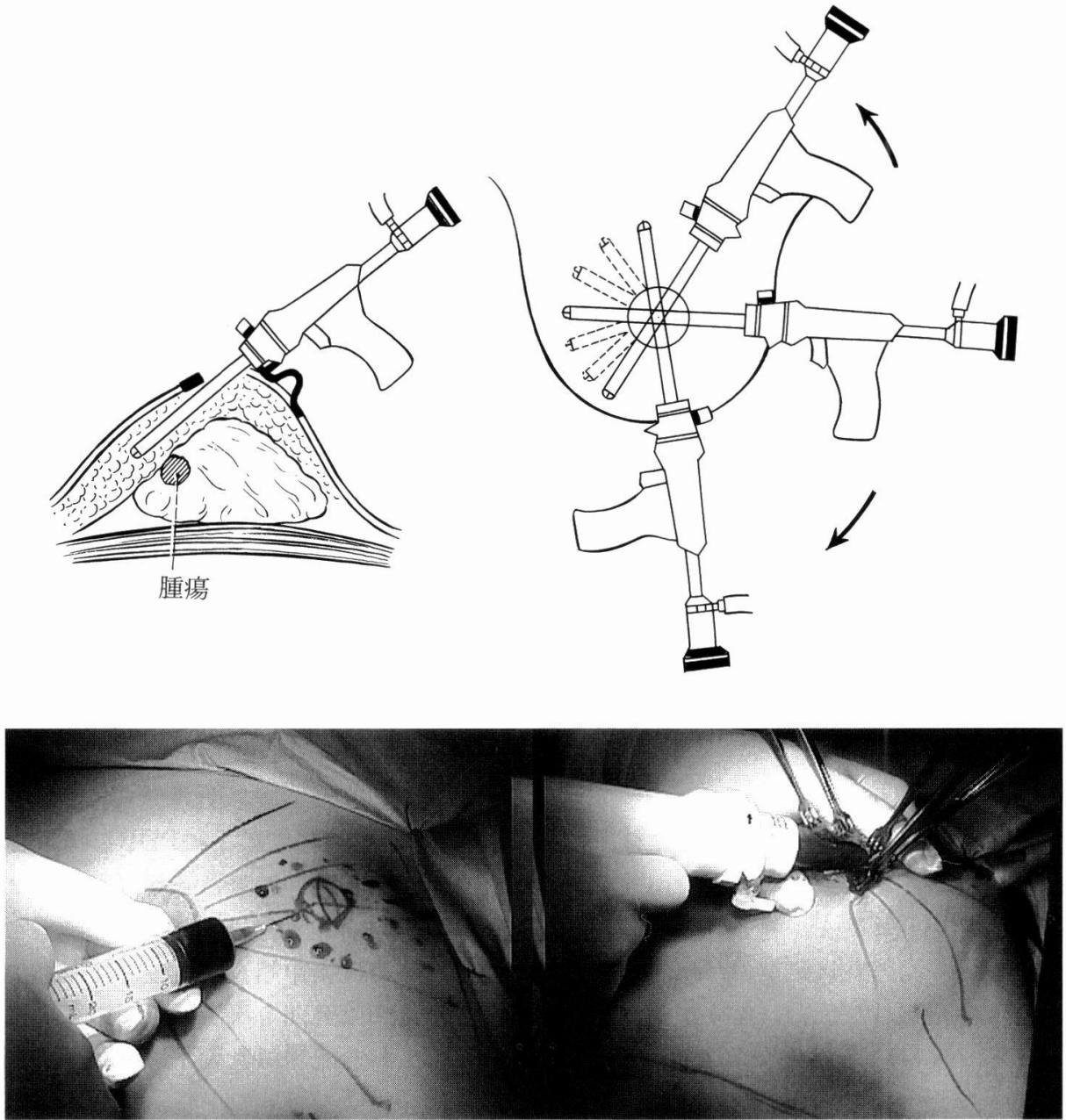

図 2-1 皮弁作製 

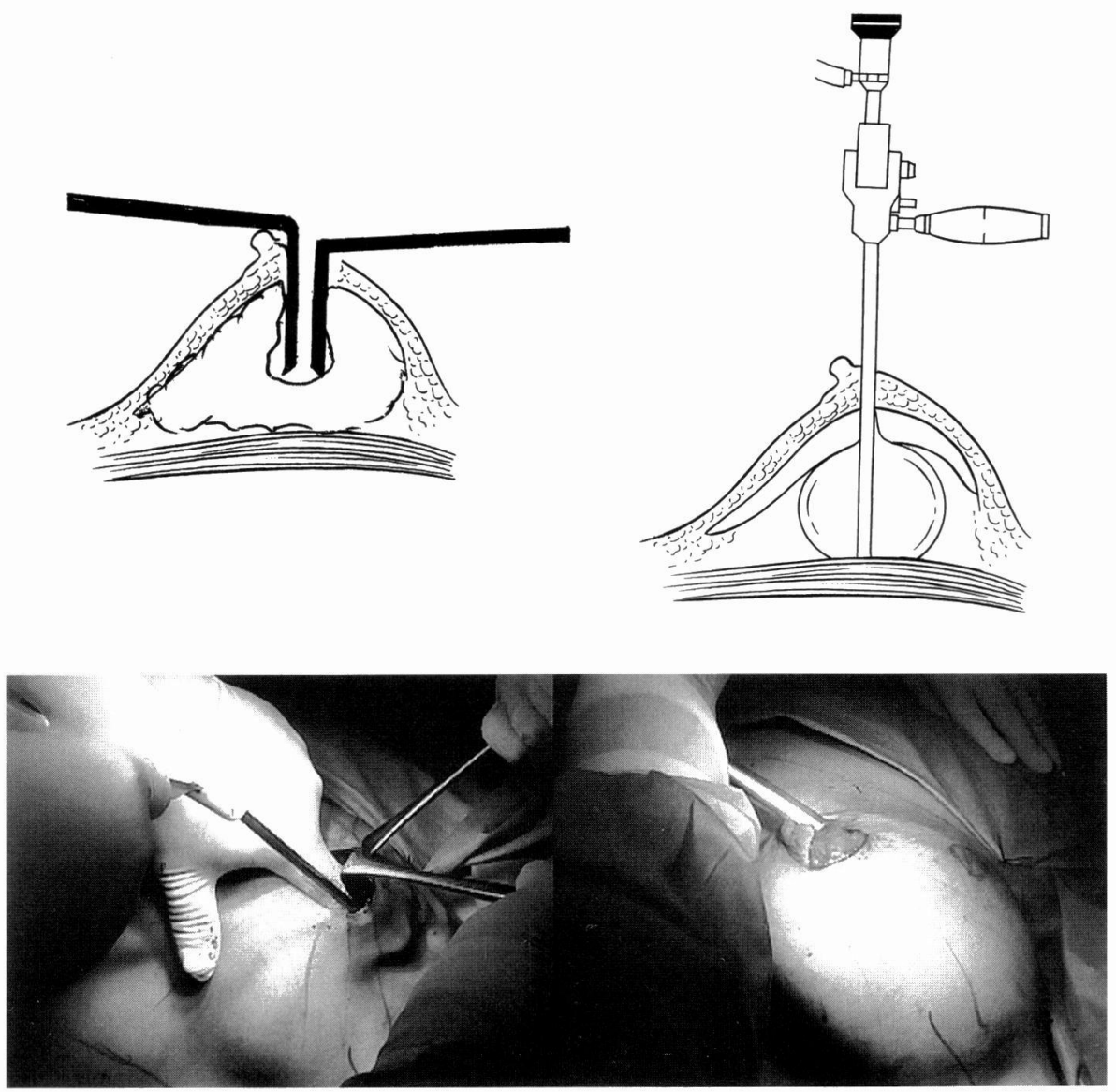

図 2-2 筋膜剝離

ている。

（1）適応；T1またはT2（ $3 \mathrm{~cm}$ 以下）で皮䖉より 腫瘍までの距離が $1 \mathrm{~cm}$ 以上あものが適応であ るが，整容性の面から切除体積が乳房全体の30\% 以下の症例が望ましい。特に全身状態には影響さ れない。

(2) 手術手技 ;

\section{a，皮弁形成}

腫瘍の占居部位を確認しマーキングした後, 切 除範囲の約 2 倍の広さを設定し $1 \sim 1.5 \mathrm{~cm}$ 間隔に 放射状に線を引き，トロカール刺入目標とする。 次に腫瘍上の皮膚浸潤の有無観察のために腫瘍直 上の皮下に30倍に希勫した色素（インジゴカルミ ン）を注射する。乳輪に約半周の切開を加之，切 開部より可視卜ロカールを挿入しあらかじめ設定 した間隔で直視下にトンネルを作製する。これを
数回繰り返し数本の皮下トンネルを形成しこのト ンネル間の皮下組織を超音波凝固装置にて切離し 皮弁を形成玄る（図 2-1）。

b，大胸筋膜の剝離

乳頭側切離予定線で乳線組織を筋鉤と電気メ久 を用いて垂直に筋膜下まで分け，筋膜をコッヘル 鉗子にて把持する。次に示指を用いて大胸筋と筋 膜の間を鈍的に剝離し小スペースを形成する（図 $2-2)$ 。その後筋膜下にPDBを扱入し大胸筋筋 膜を剝離，乳線を遊離させる（図 $2-2)$ 。

$\mathrm{c}$, 乳線の切離と再建

触診または術中超音波検查により腫瘍の局在を 再確認し切除範囲を決定後, CSにて乳腺を切離す る。切除した乳腺は乳輪下切開創から摘出する。 最後に持続吸引可能なドレーンを大胸筋前面に指 入し，乳腺を縫合し乳房を再建する。乳腺の欠損 
6. 乳癌に対する内視鏡下乳房温存手術
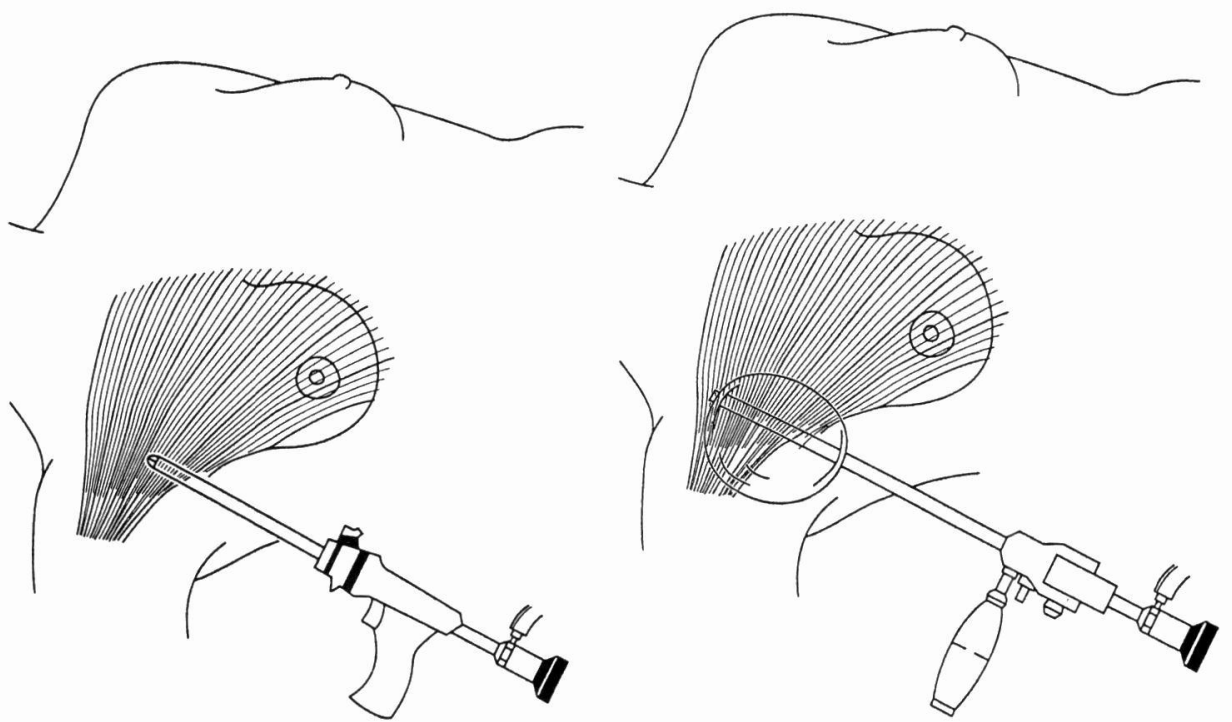

a

b

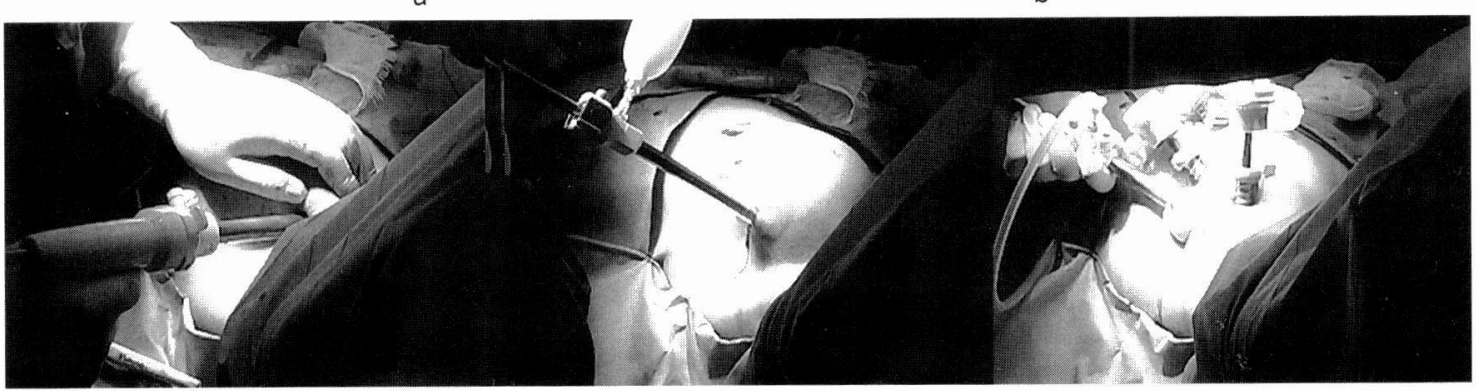

C

d

e

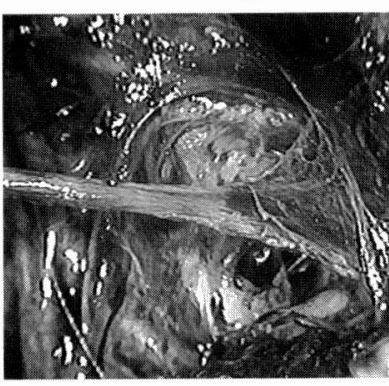

f

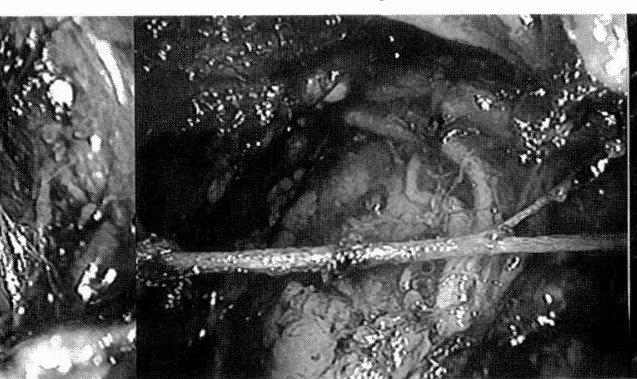

g

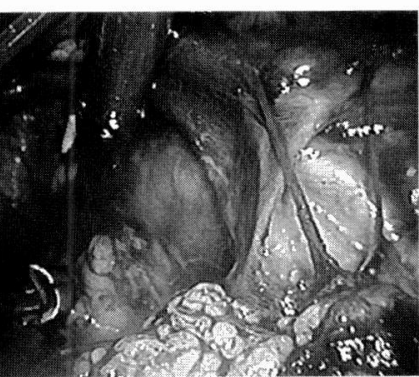

h

図 3 腋窩腔形成とトロカール配置

腋窩腔, 右 外側

中 胸背動脈周囲

左 内側

が大きい症例では側胸部または側腹部の脂肪に用 いた広背筋脂肪弁 (LTF) を用いて立填再建する。 $\mathrm{AC}$ 領域の症例については欠損を補充する必要は ない。内側の症例については遊離した乳腺を内側 へ移動した後，外側の乳腺欠損部に広背箭脂肪弁
を充填し再建する。

5, 内視鏡下腋窝リンパ節郭清術

本術式では可視トロカールにより大胸筋と腋窩 血管群の間への的確な誘導と剥離バルーンによる スペースの形成によって気囊下での視野を通常術 
式での郭清時とほぼ同じオリエンテーションで施 行できる利点がある。

(1) 適応；N0またはN1の乳癌で胸部手術既往お よび呼吸障害のない患者。

(2) 手術手技

$\mathrm{a}$, 可視卜ロカールによる腋窩腔への誘導; 中腋 窝腺上大胸筋付着部の高さに小切開をいれる。こ こにあらかじめ直視鏡を装着した可視卜ロカール を観察下に挿入し筋膜を貫き腋窩腔に誘導する。

トロカール目標として最初大胸箭外縁を目標にト ロカールをすす女その後小胸筋下まで挿入後, 卜 ロカールを左右に展開し腋窩腔を十分剥離する

(図 $3 \mathbf{a}, \mathbf{c}$ )。

b, 剝離用バルーンによる腋窩腔の剝離; トロカ 一ルを抜去後, PDBを挿入, 内視鏡直視下に付属 のポンプにより約20回加圧する。この時, PDBが 過度に剝離を進めないように加圧速度を調節しな がら注意深く剝離を進める。

剝離後, PDBを介して大胸筋, 小胸筋, 肋間上 腕神経, 鎖骨下静脈, 外側胸動静脈等が観察され る(図 $3 \mathrm{~d}$ )。

c, トロッカーの挿入; バルーン抜去後, Blunt portを挿入し固定する。ここより直視鏡を挿入し 観察下に炭酸ガスを注入し気腋窩の状態 $(8$ $\mathrm{mmHg}$ ) 設定する。次に大胸筋外縁に自分の利 き腕側にCS用の $10 \mathrm{~mm}$, 対側に把持鉗子用 $5 \mathrm{~mm}$ のトロッカーを挿入する（図 $3 \mathrm{e}$ )。

d，リンパ節郭清；まず， Blunt portより斜視鏡 (30度)，10mm trocarより CS， $5 \mathrm{~mm}$ trocarよ り把持鉗子を挿入し内側より外側に向かいリンパ 節郭清を施行する。この際カメラマンは坐位でカ メラを操作する。血管の処理はすべてCSにて行 い，結禁による血管処理は基本的には必要としな い。郭清はまず腋窩静脈をふくめた腋窩の内容を 全て背側入落とすことから始め, 胸肩峰動静脈に 注意しながら剥離を進める。鎖骨下静脈を胸郭流 入部まで十分に露出し, 脂肪組織を含めリンパ節 を郭清する。腋窩静脈より分枝する血管群は腋窩 静脈より 2 から 3 mm離れた部位でCSにてLevel 3で切断する。それ以外の組織についてはLevel 5 で切離する。次にBlunt portを抜去しこの創を約 $2.5 \mathrm{~cm}$ に延長する。 $\mathrm{S}$ 字鈎を挿入展開すると腋窩
リンパ節を含む脂肪組織を確認できるので肋間上 腕神経，下胸筋神経に注意しながらし郭清したリ ンパ節を摘出する（図 $3 \mathrm{f}, \mathrm{g}, \mathrm{h}$ )。

$\mathrm{B}$, 結果

現在までリンパ節郭清を含む内視鏡下乳房温存 手術を 113 例に, 内視鏡下乳腺全摘術を 12 例に, 内 視鏡下リンパ節郭清術のみを11例に施行した。こ のうち内視鏡下乳房温存手術を施行したものでは 平均手術時間133分, 平均出血量 $199 \mathrm{ml}$, 平均郭清 リンパ節個数13個 $(5-33$ 個), であり術中合併症 としては皮下気腫 1 例, 乳輪切開部熱傷 2 例, 術 後合併症として広背筋脂肪弁萎縮 2 例, 創感染 2 例がみられたがいずれも保存的に軽快している。 術後の乳房の形態は約 6 力月で安定し再建に伴う 症状も軽減している（図 4 ）。

C，内視鏡下乳腺手術おける今後の展望

悪性腫瘍に対する内視鏡下手術の適応について はen bloc resectionが困難なこと, 標本摘出時の 問題を初めとする手術操作上の問題に加之 port site reccurenceおよび残存腫瘍細胞に対する有効 な補助療法がないこと等の問題があり早期癌に限 定されているのが現状である11。しかし乳癌にお いては化学療法, 放射線療法の感受性が高く, 乳 癌そのものの予後も消化器癌と比較して良好であ る。そのため従来より種々の縮小手術が試みられ ており, 乳癌を対象とした種々の無作為比較対照 試験においても乳房温存療法と非定型的乳房切除 術との間で治療成績に有意差のないことが報告さ れている 2 亿 5)。これは放射線療法を始めとする補

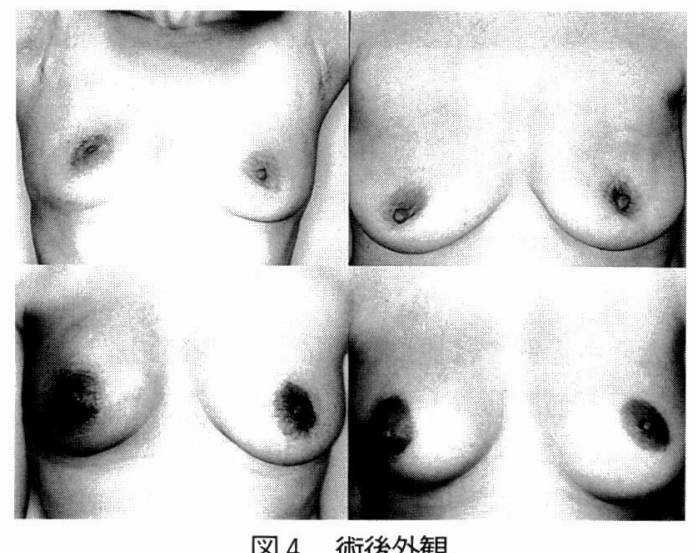

図 4 術後外観 


\section{6. 乳癌に対する内視鏡下乳房温存手術}

助療法が残存癌細胞のコントロールに有効である ことを示唆している。以上より乳癌に対する乳房 温存療法は内視鏡下手術の良い適応と考えられ る。実際, 内視鏡下乳房温存手術は短期的には通 常術式と比較しほぼ同等の成績が得られている。 生存率を含めた長期的成績については現在検討中 であるが現在まで再発を認めないことからほぼ同 等の成績が予想され, 今後乳房温存療法の一術式 として普及するものと考えている。適応について は温存手術可能である腫瘍径 ( $3 \mathrm{~cm}$ 以下) と整容 性を保持できる腫瘍径 (2.5) cm以下の間に相違が あり, 少なくとも $3 \mathrm{~cm}$ 以上の症例では内視鏡下乳 頭温存乳腺全摘術およびバッグにより乳房再建術 を施行した方が整容性に優れており今後乳腺全摘 後乳房再建術の適応が拡がるものと予想される。 次に腋窩リンパ節郭清については今後腋窩りンパ 節転移のない症例ではsentinel Lymphode biopsy 等の発達, 普及により省略されうることが予想さ れる6)。しかし腋窩リンパ節転移陽性症例ではや はり郭清が必要である。内視鏡下腋窩リンパ節郭 清術は小さい手術創で良好な視野が得られるため 比較的経験の浅い術者でも確実なLevel II の郭清 が可能であり整容性を考慮すると今後も施行され る術式であると考えている778)。以上，乳腺に対す る内視鏡下手術は乳癌という疾患の特性上良い適 応であり小さな手術創で再建を含む全ての術式が 施行できることから術者の習熟度を補う有用な手 段であり，今後ますます発展する領域であると考 えられる。

\section{参考文献}

1）福田 護: 温存療法の歴史, 渡辺 弘(監), 福田 護 (編) : 乳房温存療法のすべて.メジカルビュー 社, 1994, p 2-11

2) Fisher B, Fisher E R : The inter-relationship of hematogenous and lymphatic tumor cell dissemination. Surg Gynecol Obstet 122 : 791-798, 1996

3) Fisher B, Redmond C, Poisson R, et al : Eightyear results of the NSABP randomized clinical trial comparing total mastectomy andlumpectomy with or without irradiation in the treatment of breast cancer. N Engl J Med 320 : 822-828, 1989

4) Veronesi U, Saccozzi R, Del Vecchio MD, et al : Comparing radical mastectomy with quadrantectomy, axillary dissection, and radiotherapy in pations with small cancers of the breast. N Engl i Med $305: 6-11,1981$

5) Veronesi U, Volterrani F, Luini A, et al : Quadrantectomy versus lumpectomy for small size breast cancer. Eur J Cancer $26: 671-673,1990$

6) Veronesi U, Paganelli G, Calibti V, et al : Sentinel-node biopsy to avoid axillary dissection ically negative Lymph-node, The lancet, Vol. 349, No. 9069, p1864-1867, 1997

7) 乳癌学会編：臨床, 病理乳癌取扱い規約. 第12版, 金原出版, 1996

8）山形基夫, 長谷川哲夫, 田中 隆他：乳癌に対す る内視鏡下乳房温存手術. JSES 4 ：41-45, 1999 